\title{
Vitamin E ( $\alpha$-Tocopherol) and Vitamin C (Ascorbic Acid) Supplementation on Cholesterol and Triglyceride Blood Profile of Male Native Muscovy
}

\author{
Tugiyanti $\mathrm{E}^{1}$, Zuprizal ${ }^{2}$, Rusman ${ }^{2}$ \\ ${ }^{1}$ Faculty of Animal Science, University of Jenderal Soedirman, Jl. Dr. Soeparno Purwokerto 53123, \\ Central Java, Indonesia \\ ${ }^{2}$ Faculty of Animal Science, Gadjah Mada University, Jl. Fauna 3 Bulaksumur \\ Yogyakarta 55281, DIY, Indonesia \\ tugiyanti.elly@gmail.com
}

\begin{abstract}
This objective of this research was to evaluate vitamin $\mathrm{E}$ and $\mathrm{C}$ supplementation in feed on blood cholesterol and triglyceride profile of muscovy. Eighty four muscovy were rationed to seven (7) treatments; $\mathrm{E}_{0} \mathrm{C}_{0}$ : basal feed without vitamin $\mathrm{E}$ and $\mathrm{C}, \mathrm{E}_{400}$ : basal feed $+400 \mathrm{IU}$ vitamin $\mathrm{E}, \mathrm{E}_{600}$ : basal feed+600 IU vitamin $\mathrm{E}, \mathrm{C}_{400}$ : basal feed+400 $\mathrm{mg}$ vitamin $\mathrm{C}, \mathrm{C}_{600}$ : basal feed+600 $\mathrm{mg}$ vitamin $\mathrm{C}, \mathrm{E}_{200} \mathrm{C}_{200}$ : basal feed $+200 \mathrm{IU}$ vitamin $\mathrm{E}+200 \mathrm{mg}$ vitamin $\mathrm{C}, \mathrm{E}_{300} \mathrm{C}_{300}$ : basal feed+300 IU vitamin E+300 mg vitamin C. Completely Randomized Design was applied with 4 replicates and data were subjected to analysis of variance. Result showed that treatments significantly affected $(\mathrm{P}<0.01)$ blood cholesterol level but did not significantly affect HDL, LDL and Triglyceride levels of muscovy blood. In conclusion, vitamin $\mathrm{E}$ and vitamin $\mathrm{C}$ supplementation decreased blood cholesterol level.
\end{abstract}

Key Words: Cholesterol, Triglyceride, Muscovy, Vitamin E, Vitamin C

\section{INTRODUCTION}

Ducks significantly contribute to provide animal protein particularly meat and egg. Community awareness of health has risen. People demand low fat animal food, fowl in particular. Duck meat and egg are more preferable animal protein due to its relatively reasonable price. One hundred gram of fresh duck egg contains 189 cal energy, $13.1 \mathrm{~g}$ protein, $14.3 \mathrm{~g}$ fat, $0.8 \mathrm{~g}$ carbohydrate and $56 \mathrm{mg}$ calcium (Directorate of Nutrition, Ministry of Health RI). Male muscovy is a water fowl with high potency to produce meat (Tugiyanti et al. 2013). Damayanti (2006); Kim et al. (2006) and Heo et al. (2015) reported that duck meat contains similar protein (18.29\% vs $21.4-22.6 \%)$ and fat $(3.47 \%$ vs $4.8 \%$ ) as chicken meat, but still far from ruminants such as beef (17\%), lamb (22.4\%), and pork (32\%).

Lipid in blood plasma are cholesterol, triglyceride (TG), phospholipid and fatty acid that are insoluble in plasma liquid. These lipids require modification by protein help to be transported in blood circulation because it is not water soluble. Lipoprotein is cholesterolbearing molecule in either free form or ester trigliceryde. Phospholipid bound with protein is called apoprotein. Lipid can dissolve in lipoprotein molecule in blood circulation so it can be transported from synthesis location to the destination and distributed to body tissues (Gani et al. 2013; Santos et al. 2009).

Muscovy as well as mallard is noted for its high cholesterol level, low-density lipoprotein (LDL) and high-density lipoprotein (HDL): 136.7-203.3 mg/dl, $54.53 \mathrm{mg} / \mathrm{dl}$ and of $61.99 \mathrm{mg} / \mathrm{dl}$, respectively (Adriani et al. 2011; Wijaya et al. 2013), It was different from chicken which had 119-144.0 mg/dl, $2.34 \mathrm{mg} / \mathrm{dl}$ and $43.2 \mathrm{mg} / \mathrm{dl}$, respectively (Sutrihadi et al. 2013; Zanu et al. 2012). Cholesterol is assumed as something bad, in fact each body cell needs cholesterol. Body needs cholesterol for the formation of important steroids such as folic acid, adrenal cortex hormones, estrogen, androgen, progesterone and bile fluid. Furthermore, cholesterol supports digestive process. Cholesterol in body is 
mainly obtained from synthesis in liver whose amount depends on body need and the content from food like carbohydrate, protein or fat (Almatsier 2010).

LDL (low-density lipoprotein) is low-compact (berkerapaan rendah) lipoprotein cholesterol. LDL will gradually accumulates with other substances in capillary and cause coronary. HDL (high-density-lipoprotein), a highly compact lipoprotein, helps clean cholesterol in capillary (Lund-Katz \& Philips 2010).

Triglyceride is othe fat substance in blood. High triglyceride level is stored under the skin and serves as the main component of very low density lipoprotein (VLDL) and low density lipoprotein (LDL) in liver and absorbed in blood. Most body fat and food fat is triglyceride. High triglyceride and cholesterol triggers the susceptibility of heart disease. High cholesterol in body forms free radicals that exceeds antioxidant capacity and increases susceptibility of several diseases (Lavoisier 2008; Mayes \& Botham 2003). Antioxidant intake is therefore an alternative to maintain fowl's health.

Vitamin $\mathrm{E}$ and vitamin $\mathrm{C}$ are common and readily-available antioxidant (Tugiyanti et al. 2014). The main role of vitamin $\mathrm{E}$ is as antioxidant, particularly to protect unsaturated fatty acid in phospholipid inside membrane cell (Tappel 2008). The increasing vitamin E ( $\alpha$-tocopherol) in blood plasma will improve the ability to trap free radicals and inhibit lipid oxidation, especially matrix cells that form muscle/meat tissue (Purba \& Ketaren 2011). While vitamin $C$ is highly efficient to trap superoxide, hydrogen peroxide, hydroxyl radical, and peroxile radicals. Vitamin $\mathrm{C}$ is highly absorbable and diffusible on the upper part of small intestines then flows to blood stream through vena porta. Vitamin $\mathrm{C}$ serves as reductive agent in fluid like blood and inside cells (Yuniastuti 2008). According to Khomsan (2010), vitamin $\mathrm{C}$ is important to prevent atherosclerosis. Vitamin $\mathrm{C}$ is correlated with cholesterol metabolism, in that lacking vitamin $\mathrm{C}$ increases cholesterol synthesis. In cholesterol metabolism, vitamin C: (a) Increases the secretion rate of cholesterol in form of bile acid; (b) Increases HDL that will reduce the risk of atherosclerosis; (c) Acts as cathartic to ease excretion, thus lowers the re-absorbed bile acid and the conversion into cholesterol. Vitamin $\mathrm{E}$ synergizes with vitamin $\mathrm{C}$, the former is lipophilic while the latter is hydrophilic and can regenerate radicals vitamin E (Lavoisier 2008; Winarsi 2007).

The objective of this research was to evaluate the effect of vitamin $\mathrm{E}$ and $\mathrm{C}$ supplementation in feed on cholesterol and triglyceride profile of muscovy blood.

\section{MATERIAL AND METHODS}

The materials used were 84 nine-week-old male muscovy duck weighing 850-1100 g, kept in 28 litter cage compartments each containing three ducks. Muscovy ducks were reared for five weeks and at 14 weeks old two ducks were taken from each 2 compartment and slaughtered to take the blood to analyze the profile of cholesterol and triglyceride. Ducks were given basal fed containing $21 \%$ protein, $3100 \mathrm{kcal} / \mathrm{kg}$ feed metabolic energy (30\% corn, $7 \%$ soy bean meal, $38.20 \%$ poultry meat meal, $6.10 \%$ oil, $0.10 \%$ L-lysin HCl, $0.30 \%$ DL-methionin, $0.20 \%$ topmix, $0.10 \% \mathrm{NaCl}$ and $1 \% \mathrm{CaCO}_{3}$ ), powdered vitamin $\mathrm{E}$ (d- $\alpha$-tokoferolasetat) and vitamin $\mathrm{C}$ (L-ascorbic acid).

Equipments used were individual cages, 28 drinking water bottle and feed container and Venoject vacuum tube containing heparin anticoagulant and syringe, and materials for blood sample analysis (fat and cholesterol).

Ducks were New Castle Disesase (NCD) vaccinated at first week. Drink water was supplied ad libitum and feed was administered twice a day in the morning an afternoon. completely randomized design was applied, in which treatments were vitamin $\mathrm{E}$ and vitamin C supplementation to basal feed containing $21 \%$ protein and $3100 \mathrm{kcal} / \mathrm{kg}$ 
metabolic energy administered into seven groups namely $\mathrm{E}_{0} \mathrm{C}_{0}$ : basal feed without vitamin $\mathrm{E}$ and vitamin $\mathrm{C}, \mathrm{E}_{400}$ : basal feed plus $400 \mathrm{IU}$ vitamin $\mathrm{E}, \mathrm{E}_{600}$ : basal feed plus $600 \mathrm{IU}$ vitamin $\mathrm{E}, \mathrm{C}_{400}$ : basal feed plus $400 \mathrm{mg}$ vitamin $\mathrm{C} / \mathrm{kg}$ feed, $\mathrm{C}_{600}$ : basal feed plus $600 \mathrm{mg}$ vitamin $\mathrm{C} / \mathrm{kg}$ feed, $\mathrm{E}_{200} \mathrm{C}_{200}$ : basal feed plus $200 \mathrm{IU}$ vitamin $\mathrm{E}$ and $200 \mathrm{mg}$ vitamin $\mathrm{C} / \mathrm{kg}$ feed, and $\mathrm{E}_{300} \mathrm{C}_{300}$ : basal feed plus $300 \mathrm{IU}$ vitamin $\mathrm{E}$ and $300 \mathrm{mg}$ vitamin $\mathrm{C} / \mathrm{kg}$ feed. Each treatment was subject to four repetitions. The obtained data were then analyzed using analysis of variance and any differences were further subject to honestly significant difference test.

Laboratory test for muscovy blood profile was conducted in clinical pathology lab. Faculty of Veterinary UGM. Total blood cholesterol was measured by the enzymatic colorimetric with CHOD-PAP (Cholesterol Oxidase - Para Aminophenazone) method, while triglyceride level was analyzed by enzymatic colorimetric with GPO-PAP (glycerol phosphate oxidase-para aminophenazone) method. Triglyceride was determined based on the indicators of quinoneimin formation. HDL was measured by precipitating chylomicron, VLDL cholesterol and LDL cholesterol. LDL count is as follows:

LDL cholesterol $=$ cholesterol - HDL cholesterol $-($ triglyceride $)$

\section{RESULTS AND DISCUSSION}

Blood is main body fluid consisting of cells floated in liquid called plasma. Blood has many functions such as absorbing and carrying nutrient from digestive organs to body tissues. Cholesterol and triglyceride profile of 14 week-old male muscovy fed with supplemented vitamin $\mathrm{E}$ and $\mathrm{C}$ is presented in Table 1.

Table 1.Total cholesterol and triglyceride profile of muscovy fed with supplemented vitamin $\mathrm{E}$ and $\mathrm{C}(\mathrm{mg} / \mathrm{dl})$

\begin{tabular}{lclrc}
\hline \hline Treatments & Total cholesterol & \multicolumn{1}{c}{ HDL } & \multicolumn{1}{c}{ LDL } & Triglyceride \\
\hline $\mathrm{E}_{0} \mathrm{C}_{0}$ & $172.26 \pm 10.51^{\mathrm{a}}$ & $33.65 \pm 3.91$ & $132.33 \pm 43.85$ & $84.38 \pm 18.75$ \\
$\mathrm{E}_{400}$ & $126.32 \pm 8.59^{\mathrm{b}}$ & $41.00 \pm 5.15$ & $94.49 \pm 22.23$ & $96.88 \pm 25.76$ \\
$\mathrm{E}_{600}$ & $128.95 \pm 15.79^{\mathrm{b}}$ & $41.25 \pm 11.12$ & $87.69 \pm 20.76$ & $65.63 \pm 27.72$ \\
$\mathrm{C}_{400}$ & $131.58 \pm 18.23^{\mathrm{b}}$ & $42.15 \pm 5.54$ & $97.12 \pm 16.37$ & $56.25 \pm 21.65$ \\
$\mathrm{C}_{600}$ & $139.47 \pm 17.97^{\mathrm{b}}$ & $44.00 \pm 8.42$ & $108.63 \pm 10.06$ & $84.01 \pm 23.35$ \\
$\mathrm{E}_{200} \mathrm{C}_{200}$ & $126.32 \pm 1.56^{\mathrm{b}}$ & $41.25 \pm 5.50$ & $104.97 \pm 14.75$ & $81.75 \pm 33.95$ \\
$\mathrm{E}_{300} \mathrm{C}_{300}$ & $134.21 \pm 5.26^{\mathrm{b}}$ & $40.70 \pm 5.54$ & $101.40 \pm 5.77$ & $81.50 \pm 14.25$ \\
\hline
\end{tabular}

Values bearing different superscript within same column show highly significant effect $(\mathrm{P}<0.01)$

\section{Blood cholesterol level}

Table 1 shows that mean total blood cholesterol of muscovy was (126.32 \pm 8.59$)$ $(172.26 \pm 10.51) \mathrm{mg} / \mathrm{dl}$. Analysis of variance result showed that supplementing vitamin $\mathrm{E}$ and $\mathrm{C}$ and the combined in feed significantly $(\mathrm{P}<0.01)$ decreased total blood cholesterol level because vitamin E and C inhibited cholesterol synthesis. Huang et al. (2004) stated that antioxidant can inhibit cholesterol absorption in digestive tract, bile acid in intestines and cholesterol synthesis in liver. According to King (2010) and Harefa (2011), cholesterol synthesis follows 5 main stages: (a) Converts acetyl-CoA to 3-hydroxy-3-methylglutarylCoA (HMG-CoA); (b) Converts HMG-CoA to mevalonate; (c) Converts mevalonate to basic isoprene molecule, isopentenyl pyrophosphate (IPP) as $\mathrm{CO} 2$ is removed; 
(d) Converts IPP to squalane, (e) Converts squalane to cholesterol. Vitamin E inhibits the early stage of cholesterol synthesis.

The decreased blood cholesterol level is due to vitamin $\mathrm{E}$ and $\mathrm{C}$ as antioxidant could inhibit HMG-KoA that converts 3-hydroxy-3-methylglutaryl-CoA to mevalonic acid. Mevalonic acid is the early substance in cholesterol formation. As mevalonic decreases, cholesterol produced in liver decreases as well (Montazerifar et al. 2010). Effect of vitamin $\mathrm{C}$ is lowering total blood cholesterol level in white mice (Marsalina 2010). Khomsan (2010) confirmed that vitamin C is correlated with cholesterol metabolism and deficient vitamin $\mathrm{C}$ increases cholesterol synthesis. In cholesterol metabolism, vitamin $\mathrm{C}$ lowers cholesterol then converts approximately $80 \%$ cholesterol to bile salt. The more bile salt formed, the more cholesterol excreted thus the lower cholesterol level found in body. Vitamin $\mathrm{E}$ and $\mathrm{C}$ also react with fatty acid radicals after the substance is formed. Antioxidant vitamin E, C and the combined protect (synergize) better against oxidation and prevent fatty oxidation.

In normal metabolism, body produces free radicals in tiny but powerful particles. The atom and molecule with free electron can produce energy and play some physiological roles such as killing virus and bacteria. However, a large amount of high power radical can damage normal tissue (Pham-Huy LA et al. 2008). Free radicals are molecule with one single electron in the outer orbit such as anion superoxide $\left(\mathrm{O}_{2}^{-}\right)$, radicalhidroxyle $(\mathrm{OH})$ and hydrogen peroxide $\left(\mathrm{H}_{2} \mathrm{O}_{2}\right)$ that are so unstable and reactive. They can trigger damage in cell components like DNA, lipid, protein and carbohydrate that cause biological disorders, among which are arterosclerosis, cancer, diabetes and other degenerative diseases (Chludil et al. 2008). Vitamin $C$ and $E$ as antioxidant can cease free radicals chain reaction. Vitamin $\mathrm{E}$ will first trap free radicals and turn into vitamin $\mathrm{E}$ radicals. Vitamin $\mathrm{E}$ needs to synergize with vitamin $C$ to inhibit oxidative reaction and bind vitamin $E$ when free radicals chain is broken. The bound vitamin $\mathrm{E}$ is converted into free vitamin $\mathrm{E}$ and recovered its antioxidant function (Christijanti et al. 2010).

\section{Blood HDL level}

HDL is lipoprotein that transports cholesterol from extra hepar into antiatherogenic hepar. HDL, also called $\alpha$-lipoprotein, is the smallest lipoprotein measuring $8-11 \mathrm{~nm}$ but also the heaviest unit weight with the smallest lipid core. Twenty most dominant lipid elements in HDL is cholesterol and phospholipid. HDL is comprised of $20 \%$ cholesterol, $<5 \%$ triglyceride, $30 \%$ phospholipid and $50 \%$ protein. HDL cholesterol consists of Apo I, Apo-II, Apo C, Apo E, and Apo D (Bull \& Morrell 2007).

Table 1 shows that vitamin E, $\mathrm{C}$ and the combined supplementation did not significantly $(\mathrm{P}<0.01)$ increase $\mathrm{HDL}$ blood cholesterol level of muscovy duck. HDL synthesis is related with the return of excessive cholesterol from body tissues to liver then excrete it with bile salt. Vitamin $\mathrm{E}$ and $\mathrm{C}$ supplement could not significantly increase HDL because the response of HDL cholesterol differed across individuals depending on cholesterol intensity and initial condition. Vitamin $\mathrm{E}$ and $\mathrm{C}$ significantly increased bile excretion and inhibited cholesterol absorption; however, since cholesterol is used to synthesize folic acid, steroid hormone and bile fluid, the amount of cholesterol transported to liver decreased, thereby significantly affecting HDL synthesis.

HDL breakdown occurs in heparin. Two ways of HDL transport to heparin are scavenger receptor class B type 1 (SR-B1) as heparin scavenger receptor, and VLDL and LDL by CETP enzymes as glycoprotein plasma that contributes to exchange cholesterol ether in HDL with triglyceride in LDL. The triglyceride-enriched HDL particles will return to heparin. 
Fatmawati (2008) confirmed that antioxidant would increase HDL by increasing liver mRNA Apolipoprotein A (Apo-A) to initiate Apo-A synthesis where Apo-A is HDL main component.

\section{Blood LDL level}

LDL is lipoprotein that transports cholesterol to peripheral tissue and contributes to the synthesis of membrane and steroid hormone. LDL contains $10 \%$ triglyceride, $40 \%$ cholesterol and ether cholesterol, 30\% phospholipid and 20\% protein (Ashen \& Blumenthal 2006). The contributing factors to LDL are cholesterol level in feed, saturated fatty acid, synthesis rate and LDL and VLDL excretion in body.

Table 1 shows that vitamin $\mathrm{E}, \mathrm{C}$ and the combined supplement could not significantly $(\mathrm{P}>0.05)$ lower LDL level in muscovy blood because LDL is determined by body cholesterol and cholesterol intake, feed, synthesis rate and LDL and VLDL excretion in body. LDL contains high cholesterol. Cholesterol level in muscovy duck in this research is assumedly sufficient for LDL synthesis so that LDL in blood did not significantly decrease. About 50\% LDL is synthesized by peripheral tissue and the rest $50 \%$ is taken by heparin (Hanafi 2007). LDL undergoes catabolism through LDL dependent-receptor pathway on the surface of lliver cells and receptor-independent pathways. Receptormediated catabolism is limited by endogen cholesterol production. LDL is the "bad" cholesterol because it is easily attached to the inner capillary (Ashen \& Blumenthal 2006; Botham \& Mayes 2009).

The increasing LDL level suppresses HDL and inhibits the discharge of excessive cholesterol in blood, thereby HDL decreases. Body tissue will use cholesterol from HDL to compose membrane, synthesize steroid hormone and given the excessive amount will cause aterosclerosis (Hanafi 2007).

\section{Blood triglyceride level}

Triglyceride is fatty acid and the most blood-circulating fat. Truglyceride is mainly transported as chylomicrons from intestines to heparin, undergoes metabolism, then mostly as VLDL is transported from heparin to all body tissues.

Vitamin $\mathrm{E}$ and $\mathrm{C}$ supplementation did not significantly affected $(\mathrm{P}>0.05)$ triglyceride level. Despite the increased bile acid secretion that lowered blood cholesterol level, lipase lipoprotein activity was still high and not transported to body parts, accordingly triglyceride was not significantly decreased (Philips 2013). Besides, vitamin C is only effective to lower the high triglyceride level, not the normal level, so vitamin $\mathrm{C}$ only maintains balance (homeostatis) in body.

Vitamin E and C improved antioxidant status but did not decrease triglyceride level. Other contributing factor to the insignificant decrease of triglyceride was the activity of cytochrome P-450 that mediated hydroxylation reaction, thus multiplying free radicals that obstructed Apo-C2. Apo-C2 is the cofactor of lipoprotein lipase, thus the obstructed ApoC2 would distracted lipase lipoprotein function. Accordingly, chylomicron composed of tryglicerides would accumulated in serum (Nugraha 2008; Guyton \& Hall 2011). However, vitamin E and C tended to lower triglyceride level (Table 1). Triglyceride level depends on cholesterol synthesis. Cholesterol is excreted upon conversion into bile acid. $\alpha$ -hydroxilation reaction is preliminary in bile acid biosynthesis (King 2010). 


\section{CONCLUSION}

Vitamin $\mathrm{E}$ and $\mathrm{C}$ supplementation in feed tended to lower blood cholesterol, LDL, and triglyceride but increased HDL of male muscovy.

\section{ACKNOWLEDGEMENT}

The author would like to thank to Directorate General of Higher Education, Ministry of Education and Culture for the Doctorate scholarship in Post Graduate Animal Science Study Program, Gadjah Mada University Yogyakarta. Gratitude also goes to the Dean of Animal Science Faculty, Jenderal Soedirman University for granting study permit.

\section{REFERENCES}

Adriani L, Mayasari, Angga N, Kartasudjana, R. 2011. The effect of fermented Kombucha tea on HDL, LDL and Total Cholesterol levels in the duck bloods. Faculty of Animal Husbandry, Padjadjaran University, Bandung. Indonesia. Biotechnol Anim Husb. 27:1749-1755.

Almatsier S. 2010. Basic orinciple of nutrition science: Lipida. Jakarta (Indonesia): Gramedia Pustaka Umum. p. 63.

Ashen MD, Blumenthal RS. 2006. Low LDL cholesterol level. New Engl Med. 352:1252-1262.

Botham KM, Mayes PA. 2009. Harper's illustrated biochemistry: Cholesterol synthesis, transpor \& excretion. New York (USA): McGraw Hill. p. 239-248.

Bull E, Morrell J. 2007. Simple guides cholesterol. 1st Ed. Jakarta (Indonesia): Erlangga.

Chludil HD, Corbino GB, Leicarh SR. 2008., Soil quality effects on chenopodium album flavonoid content and antioxidant potential. J Agric Food Chem. 56:5050-5056.

Christijanti W, Utami NR, Iswara A. 2010. The antioxidant effects of vitamin C and E on the spermatozoa quality of allethrin-induced albino rats. Biosaintifika. 2:18-26.

Damayanti AP. 2006. Protein, meat and skin fat of eight-week-old muscovy, mallard and mandaulung. J Agroland. 13:313-317.

Directorate of Nutrition, Ministry of Health. RI. 2010. Food Composition Database. Jakarta (Indonesia): Bharata.

Fatmawati. 2008. Effect of supplementation duration of extract sambiloto leaves on cholesterol, LDL, HDL and triglyceride of diabetic mice. [Undergraduate Thesis]. Malang (Indonesia): Universitas Islam Negeri Malang.

Gani HBS, Wongkar D, Ticoalu SHR. 2013. Comparison of high density lipoprotein cholesterol in obbese and non-obbese women. J e-Biomedik. 1:879-883.

Guyton AC, Hall JE. 2011. Medical phisiology module. 11th Ed. In: Irawati, translator. Rachman LY, editor. Buku Ajar Fisiologi Kedokteran. Jakarta (Indonesia): EGC.

Hanafi M. 2007. Lipid metabolism. Surabaya (Indonesia): FK UNAIR.

Harefa K. 2011. Effect of physical activity and green tea (Camellia sinensis) extract on lipid profile of male mice (Mus musculus) strain DD Webster with high fatty feed. [Undergraduate Thesis]. Medan (Indonesia): Universitas Sumatra Utara.

Heo KN, Honga EC, Kim CD, Kim HK, Lee MJ, Choo HJ, Choi H, Mushtaq MMH, Parvin R, Kim JH. 2015. Growth performance, carcass yield, and quality and chemical traits of meat from commercial Korean native ducks with 2-way crossbreeding. Australas J Anim Sci. 28:382-390. 
Huang DJ, Lin CD, Chen HJ, Lin YH. 2004. Antioxidant and antiproliferative activities of sweet potato (Ipomoea batatas L. Lam Tainong 57) constituents. Bot Bull Acad Sin. 45:179-186.

Lund-Katz S, Phillip MC.2010. High Density Lipoprotein Structure-Function and Role in Reverse Cholesterol Transport. Subcell Biochem. 51:183-227.

Khomsan A. 2010. Food and nutrition for health. Jakarta (Indonesia): Gramedia Pustaka Utama.

Kim GD, Jeong YJ, Moon SH, Hwang YH, Park GB, Joo ST. 2006. Effects of muscle fibre type on meat characteristics of chiken and ducks breast muscle. Division of Applied Life Science, Graduate School, Gyeongsang National University, Jinju, Gyeongnam 660-701, Korea. p. 1-3.

King MW. 2010. Cholesterol and bile synthesis and metabolism. Available at http://themedicalbiochemistry.org/cholesterol.html. [cited 25 March 2016, 14:25].

Lavoisier AL. 2008. Chemical and physiological properties of vitamins. In: Combs GF, editor. The vitamins, fundamental aspects in nutrition and health. Third Edition. London (UK): Academic Press. p. 35-74.

Marsalina M. 2010. Effect of water extract of rosela flower (Hibiscus sabdariffa L.) on total blood cholesterol and body weight of albino mice (Rattus norvegicus). [Undergraduate Thesis]. [Surakarta (Indonesia)]: Universitas Sebelas Maret.

Mayes PA, Botham KM. 2003 Lipid transport and storage. In: Murray, Robert K, Granner, Daryl K, Mayes A, Rodwell P, Victor W, editors. Harper Illustrated Biochemistry. 26th ed. New York (USA): Lange Medical Books/Mc Graw-Hill. p. 205-218.

Montazerifar F, Hashemi M, Karajibani M, Dikshit M. 2010. Effect of antioxidant vitamins on lipid profile and total antioxidant capacity in hemodialysis patients. RMJ 35:120-123.

Murray RK, Granner DK, Rodwell VW. 2006. Biokimia Harper. Jakarta (Indonesia): Medical Science Book EGC.

Nugraha A. 2008. Effect of rambutan (Naphelium lappaceum L.) Skin on total cholesterol serum level in wistar mice. Artikel Ilmiah. Semarang (Indonesia): Universitas Diponegoro.

Pham-Huy LA, He H, Pham-Huy C. 2008. Review article: Free radicals, antioxidants in disease and health. Int J Biomed Sci. 4:89-96.

Phillips MC. 2013. Thematic review series: High density lipoprotein structure, function, and metabolism-new insights into the determination of HDL structure by apolipoproteins. J Lipid Res. 54:2034-2048.

Purba M, Ketaren PP. 2011. Feed Consumption and Conversion of 8-week-old Male Native Duck with Santoquin and Vitamin E supplemented in Feed. JITV. 16:280-287.

Qin Y, Xia M, Ma J, Hao YT, Liu J, Mou HY, Cao L, Ling WH. 2009. Anthocyanin supplementation improves serum LDL and HDL-cholesterol concentration associated wuth the inhibition of cholesteryl ester transfer protein in dyslipidemic subjects. Am J Clin Nutr.. 90:485-492.

Santos RD, Waters DD, Tarasenko L, Messig M, Jukema JW, Ferrières J, Verdejo J, Chiang CW. 2009. Low-and high-density lipoprotein cholesterol goal attainment in dyslipidemic women: The lipid treatment assessment project (L-TAP) 2. Am Heart J. 158:860-866.

Sormin IP, Lukito W, Wijaya A, Suryani. 2010. High Density Lipoprotein (HDL) Biogenesis Disorder in Adult Male with Metabolic Syndrome. Majalah Kedokteran Ind. 60(8):351-355.

Sutrihadi E, Suhermiyati, Iriyanti N. 2013. The additional of turmeric (Curcuma domestica Val) and sambiloto (Andrograpphis paniculata Nees) flour in diet on blood cholesterol and meat cholesterol broiler). Jurnal Ilmiah Peternakan 1:314-322. 
Tugiyanti E, Yuwanta T, Zuprizal, Rusman. 2013. Improving performance, meat quality and muscle fiber microstructure of native Indonesian muscovy duck through feed protein and metabolizable energy. Int J Poult Sci. 12:653-659.

Tugiyanti E, Yuwanta T, Zuprizal, Rusman. 2014. Supplementation of Vitamin E and C in Feed on Meat Quality, Thiobarbituric acid reactive (Tbars) and mioglobin level of muscovy duck meat. J.Ind. Trop.Anim.Agric. 39:37-44.

Wijaya VG, Ismoyowati, Saleh DM. 2013. Study cholesterol and triglyceride levels blood of various local duck feed supplemented with probiotics.. Jurnal Ilmiah Peternakan. 1:661-668.

Winarsi H. 2007. Natural Antioxidant and Free Radicals. Yogyakarta (Indonesia): Kanisius. p. 122-211.

Yuniastuti A. 2008. Gizi dan kesehatan. Edisi ke-1. Yogyakarta (Indonesia): Graha Ilmu.

Zanu HK, Asiedu, P, Tampuori M, Abada M, Asante I. 2012. Possibilities of using Moringa (Moringa oleifera) leaf meal as partial substitutefor fishmeal in broiler chicken diets. Online $\mathrm{J}$ Anim Feed Res. 2:70-75.

\section{DISCUSSION}

\section{Questions}

1. What is the main effect of vitamin $E$ and $C$ in your research?

2. What is the effect of the combination of vitamin $E$ and $C$

\section{Answers}

1. Vitamin E has its main effect on the triglyceride blood

2. Vitamin $C$ has its main effect on cholesterol blood, but the combination of the vitamin $E$ and $C$ have not significant effect on cholesterol and triglyceride 